\title{
MENINGKATKAN KEMAMPUAN MEMBACA MELALUI PENERAPAN METODE SQ3R (SURVEY, QUESTION, READ, RECITE, REVIEW) DI SEKOLAH DASAR
}

\author{
Sakka $^{1, a)}$, La Rabani ${ }^{2}$ \\ ${ }^{1}$ Alumni Jurusan Pendidikan Guru Sekolah Dasar, FKIP Universitas Halu Oleo, \\ J1. H.E.A. Mokodompit Kendari 93232, Indonesia \\ ${ }^{2}$ Dosen FKIP Universitas Halu Oleo, Jl. H.E.A. Mokodompit Kendari 93232, \\ Indonesia \\ a)e-mail: sakka234@gmail.com
}

\begin{abstract}
ABSTRAK
Penelitian ini bertujuan untuk meningkatkan kemampuan membaca siswa melalui penerapan metode SQ3R (survey, question, read, recite, review). Penelitian ini dilaksanakan pada semester genap tahun pelajaran 2015/2016 bertempat di Kelas VI SDN Lemo Bajo Kabupaten Konawe Utara. Jenis data yang didapatkan dalam penelitian ini adalah data kualitatif dan data kuantitatif. Hasil penelitian menunjukkan bahwa: (1) persentase keberhasilan aktivitas mengajar guru siklus I pertemuan pertama adalah $68,00 \%$ dan pertemuan kedua $74,67 \%$, meningkat menjadi $81,33 \%$ pada siklus II pertemuan pertama dan 94,67\% pertemuan kedua, (2) persentase keberhasilan aktivitas belajar siswa siklus I pertemuan pertama adalah $68,00 \%$ dan pertemuan kedua $73,33 \%$, meningkat menjadi $81,33 \%$ pada siklus II pertemuan pertama dan $94,67 \%$ pertemuan kedua, (3) rata-rata nilai siswa siklus I adalah 69,81 meningkat menjadi 81,15 pada siklus II. Ketuntasan belajar siswa pada siklus I adalah 61,54\% meningkat menjadi 92,31\% pada siklus II.
\end{abstract}

Kata kunci: kemampuan membaca, SQ3R.

\author{
IMPROVING THE ABILITY TO READ THROUGH THE APPLICATION OF THE SQ3R \\ METHOD (SURVEY, QUESTION, READ, RECITE, REVIEW) \\ IN CLASS VI STUDENTS OF SDN LEMO BAJO \\ NORTH KONAWE REGENCY
}

\begin{abstract}
This study aims to improve students' reading ability through the application of the SQ3R method (survey, question, read, recite, review). This research was carried out in the even semester of 2015/2016 school year in Class VI SDN Lemo Bajo, North Konawe Regency. The type of data obtained in this study is qualitative data and quantitative data. The results showed that: (1) the percentage of success of teacher teaching activities in the first cycle of the first meeting was $68.00 \%$ and the second meeting was $74.67 \%$, increasing to $81.33 \%$ in the second cycle of the first meeting and $94.67 \%$ in the second meeting, (2) the percentage of success of student learning activities in the first cycle of the first meeting was $68.00 \%$ and the second meeting was $73.33 \%$, increasing to $81.33 \%$ in the second cycle of the first meeting and $94.67 \%$ in the second meeting, (3) the average score First cycle students were 69.81 increasing to 81.15 in cycle II. Student learning completeness in cycle I was $61.54 \%$ increasing to $92.31 \%$ in cycle II.
\end{abstract}

Keyword: reading ability, $S Q 3 R$. 


\section{Pendahuluan}

Seiring dengan perkembangan teknologi informasi, dunia pendidikan dituntut untuk menghasilkan sumber daya manusia yang handal. Sumber daya yang dimaksud tidak tercipta hanya melalui pendidikan tinggi, melainkan diawali dari pendidikan dasar dan menengah. Pendidikan dalam kajian ini untuk selanjutnya adalah dalam konteks pendidikan formal, maka yang dimaksud pendidikan adalah pembelajaran (Dimyati dan Mudjono, 2003:12).

Pembelajaran Bahasa Indonesia di Sekolah Dasar bertujuan meningkatkan kemampuan siswa berkomunikasi secara efektif, baik lisan maupun tertulis. Kemampuan membaca sebagai salah satu ketrampilan berbahasa tulis yang bersifat reseptif perlu dimiliki siswa SD agar mampu berkomunikasi secara tertulis. Oleh karena itu, peranan pengajaran Bahasa Indonesia khususnya pengajaran membaca di SD menjadi sangat penting. Peran tersebut semakin penting bila dikaitkan dengan tuntutan pemilikan kemahirwacanaan dalam abad informasi. Pengajaran Bahasa Indonesia di SD yang bertumpu pada kemampuan dasar membaca dan menulis juga perlu diarahkan pada tercapainya kemahirwacanaan. Keterampilan membaca harus segera dikuasai oleh para siswa di SD karena ketrampilan ini secara langsung berkaitan dengan seluruh proses belajar siswa di SD. Keberhasilan belajar siswa dalam mengikuti proses kegiatan belajarmengajar di sekolah sangat ditentukan oleh penguasaan kemampuan membaca mereka. Siswa yang tidak mampu membaca dengan baik akan mengalami kesulitan dalam mengikuti kegiatan pembelajaran untuk semua mata pelajaran. Siswa akan mengalami kesulitan dalam menangkap dan memahami informasi yang disajikan dalam berbagai buku pelajaran, buku-buku bahan penunjang dan sumber-sumber belajar tertulis yang lain. Akibatnya, kemajuan belajarnya juga lamban jika dibandingkan dengan teman-temannya yang tidak mengalami kesulitan dalam membaca.

Berdasarkan pengamatan peneliti sebagai guru kelas VI SD Negeri Lemo Bajo, kemampuan membaca siswa masih sangat rendah. Hal itu dapat dilihat dari rata-rata nilai siswa pada materi membaca tahun ajaran 2014/2015 yakni 66,71. Nilai tersebut merupakan nilai rata-rata dari 24 orang siswa kelas VI SD Negeri Lemo Bajo. Dari 24 orang siswa tersebut hanya 13 orang $(54,17 \%)$ siswa yang mampu memahami isi bacaan dengan baik sedangkan 11 orang $(45,83 \%)$ siswa belum mampu memahami isi bacaan. Kegiatan membaca perlu dibiasakan sejak dini, yakni mulai dari anak mengenal huruf. Kegiatan membaca harus dijadikan sebagai suatu kebutuhan dan menyenangkan bagi siswa. Membaca dapat dilakukan dimana saja dan kapan saja, asal ada keinginan, semangat dan motivasi. Bagi siswa, membaca merupakan sesuatu yang sangat penting karena merupakan keterampilan utama untuk memudahkan siswa memahami materi pelajaran (Soedarso, 2004:35). Perbaikan proses pembelajaran memegang peranan penting dalam meningkatkan mutu pendidikan. Hasil observasi awal peneliti pada siswa kelas VI SD Negeri Lemo Bajo, ditemukan beberapa masalah yang dialami siswa dalam proses pembelajaran yakni; (1) masih banyak siswa tidak suka membaca, (2) siswa tidak aktif dalam proses pembelajaran. Masalah tersebut muncul sebagai akibat dari pendekatan pembelajaran yang diterapkan guru tidak cocok dengan materi pembelajaran sehingga harus diatasi agar kemampuan membaca siswa meningkat dan siswa aktif dalam proses pembelajaran.

Salah satu metode pembelajaran yang dapat diterapkan untuk meningkatkan kemampuan membaca siswa adalah metode SQ3R. Metode SQ3R merupakan kependekan dari survey, question, read, recite, dan review. Keunggulan metode SQ3R adalah adanya tahap survey terhadap bacaan yang dihadapi memberi kemungkinan pada pembaca untuk menentukan apakah materi yang akan dibaca sesuai dengan keperluannya atau tidak. Metode SQ3R memberi kesempatan kepada para pembaca untuk berlaku fleksibel, artinya pengaturan kecepatan membaca untuk setiap bagian bahan bacaan tidaklah harus sama. Pembaca akan memperlambat tempo bacaannya manakala bertemu dengan hal-hal yang relatif baru baginya, yang memerlukan perenungan untuk dapat memahaminya, dan bagian-bagian bacaan yang berisi informasi yang diperlukan. Sebaliknya, pembaca akan menaikkan tempo kecepatan bacanya, jika bagian-bagian bacaan itu dipandang kurang 
relevan dengan kebutuhannya atau sudah dikenalinya.

Penerapan metode SQ3R dalam proses pembelajaran membaca akan menghasilkan efisiensi dan efektifitas hasil belajar yang lebih baik. Penerapan metode ini dalam pembelajaran akan menghasilkan pemahaman yang komprehensif, bukan ingatan. Pemahaman yang komprehensif relatif akan bertahan lebih lama tersimpan di dalam otak siswa, daripada hanya sekadar mengingat fakta. Dalam rangka meningkatkan kemampuan membaca siswa, maka guru harus menerapkan metode pembelajaran membaca yang tepat dalam proses pembelajaran di kelas. Penerapan metode pembelajar yang tepat akan menumbuhkan minat baca dan keaktifan belajar membaca siswa.

Penelitian yang relevan dengan penelitian ini adalah penelitian yang dilakukan oleh Lukman (2009) berjudul "Peningkatan Kemampuan Membaca dengan Strategi SQ3R pada Siswa Kelas VI SDN 2 Nganganaumala Kota Bau-Bau Tahun Ajaran 2009/2010" menyimpulkan dua hal berikut. Pertama terjadi peningkatan kemampuan membaca siswa dengan bukti skor rata-rata kelas pada pra tindakan sebesar 56,51atau berada dalam kategori kurang. Pada siklus I rata-rata kelas mengalami peningkatan sebesar 10,95\% menjadi 67,46 atau berada pada kategori cukup. Pada siklus II rata-rata kelas meningkat menjadi 81 pada kategori baik. Hal ini berarti terjadi peningkatan dari siklus I ke siklus II sebesar $13,54 \%$. Kedua terjadi perubahan perilaku siswa pada pembelajaran membaca setelah menggunakan strategi SQ3R. Penelitian relevan selanjutnya adalah penelitian yang dilakukan oleh La Mica (2010) berjudul "Meningkatkan Kemampuan Membaca Siswa Kelas VI SDN 2 Wamboule Kabupaten Buton Utara melalui Metode SQ3R" berkesimpulan bahwa kemampuan membaca siswa kelas VI SDN 2 Wamboule Kabupaten Buton Utara dapat ditingkatkan melalui Metode SQ3R. Pada siklus I rata-rata nilai siswa adalah 66,75 meningkat menjadi 74,56 pada siklus II. Berdasarkan hal tersebut, maka penulis ingin meningkatkan kemampuan membaca siswa dengan melakukan penelitian tindakan kelas berjudul "Meningkatkan Kemampuan Membaca Melalui Penerapan Metode SQ3R (Survey, Question, Read, Recite,
Review) pada Siswa Kelas VI SDN Lemo Bajo Kabupaten Konawe Utara"

\section{Metode Penelitian}

Penelitian ini termasuk dalam jenis penelitian tindakan kelas. Karakteristik yang khas dari penelitian tindakan kelas yakni adanya tindakan-tindakan tertentu untuk memperbaiki proses dan hasil belajar mengajar di kelas (Muhtar, 2000). Penelitian ini dilaksanakan pada semester genap tahun pelajaran 2015/2016 bertempat di SD Negeri Lemo Bajo Kabupaten Konawe Utara. Subjek penelitian ini adalah siswa dan guru kelas VI SD Negeri Lemo Bajo Kabupaten Konawe Utara. Jumlah siswa sebanyak 26 orang, masing-masing terdiri dari 14 orang siswa perempuan dan 12 orang laki-laki. Untuk mampu menjawab permasalahan penelitian, ada beberapa faktor yang akan diteliti. Faktorfaktor tersebut adalah sebagai berikut.

1. Faktor siswa: yaitu mengamati aktivitas siswa dalam mempelajari Bahasa Indonesia khususnya pada saat pembelajaran membaca, dan kemampuan membaca siswa.

2. Faktor guru: yaitu mengamati guru dalam menyajikan materi membaca dengan menggunakan metode SQ3R.

3. Faktor kemampuan membaca: untuk membandingkan kemampuan membaca siswa sebelum dan sesudah dilaksanakan tindakan

Penelitian ini merupakan Penelitian Tindakan Kelas (PTK) yang dilaksanakan dalam beberapa siklus, tiap siklus terdiri atas empat langkah berikut: (1) perencanaan (planning); (2) pelaksanaan tindakan (action); (3) observasi dan evaluasi (observation and evaluation); (4) refleksi (reflection). Sumber data penelitian ini adalah guru dan siswa kelas VI SD Negeri Lemo Bajo Kabupaten Konawe Utara. Jenis data yang didapatkan dalam penelitian ini adalah data kualitatif dan data kuantitatif yang dijabarkan sebagai berikut 1) Data kualitatatif berupa aktivitas siswa dan guru dalam proses pembelajaran dan 2) Data kuantitatif berupa kemampuan membaca siswa dalam bentuk nilai.

Data dikumpulkan dari hasil tindakan yang dilakukan pada proses pembelajaran yang dijabarkan sebagai berikut: 1) Observasi dilakukan untuk mengumpulkan data aktivitas 
siswa dan guru dalam proses pembelajaran. Observasi aktivitas siswa dan guru dalam proses pembelajaran dilakukan oleh teman sejawat, 2) Tes dilakukan untuk mengetahui kemampuan membaca siswa pada setiap akhir siklus tindakan.

Data penilitian ini dianalisis secara deskriptif kuantitatif dan kualitatif. Deskripsi kualitatif digunakan untuk menganalisis aktivitas guru dan siswa selama proses pembelajaran membaca dengan metode SQ3R. Sedangkan deskriptif kuantitatif digunakan untuk menganalisis data peningkatan kemampuan membaca siswa setelah pembelajaran dilaksanakan dalam setiap siklusnya. Untuk menentukan kemampuan membaca siswa, peneliti melakukan tes membaca. Untuk memudahkan dalam melakukan penilaian, peneliti menggunakan rubrik untuk menentukan skor siswa. Aktivitas guru dan siswa selama proses pembelajaran membaca dengan metode SQ3R diamati oleh observer untuk menentukan keberhasilan proses pembelajaran berdasarkan keterlaksanaan skenario pembelajaran. Indikator keberhasilan penelitian ini adalah kemampuan membaca siswa dan keberhasilan proses pembelajaran. Siswa dikatakan telah memiliki kemampuan membaca sekilas, apabila minimal $80 \%$ siswa telah mendapat nilai $\geq 70$. Proses pembelajaran dikatakan berhasil, jika proses pembelajaran dilaksanakan sesuai dengan skenario pembelajaran.

\section{Hasil Penelitian dan Pembahasan}

\section{Tindakan Siklus I}

Pada pertemuan pertama kegiatan awal yang dilakukan guru adalah menyampaikan tujuan pembelajaran yakni: (a) siswa dapat menemukan informasi dari teks yang dibaca, dan (b) siswa dapat menentukan gagasan utama tiap-tiap paragraf teks yang dibacanya. Selanjutnya guru menjelaskan proses pembelajaran dengan metode SQ3R. Setelah menyampaikan tujuan pembelajaran, guru mengadakan apersepsi melalui pertanyaan berikut: (a) siapa yang suka membaca buku pelajaran? (b) pernahkah anda membaca buku cerita? Untuk membangkitkan respon siswa, guru melakukan tanya jawab tentang hobi membaca, dan keuntungan membaca sebagai berikut: (a) apakah manfaat membaca? (b) agar mendapatkan banyak informasi apakah kita harus rajin membaca. Setelah masuk kegiatan inti, guru membagikan lembar kerja siswa (LKS) dalam bentuk teks bacaaan yang berjudul "Tawuran Pelajar Memprihatinkan Dunia Pendidikan" dan daftar pertanyaan kepada masing-masing siswa selanjutnya menjelaskan kepada siswa cara mengerjakan LKS. Guru mengarahkan siswa untuk melakukan survey teks bacaan. Guru membimbing siswa membuat pertanyaan tentang isi bacaan (question). Guru mengarahkan siswa membaca teks bacaan (read). Guru membimbing siswa menjawab pertanyaan (recite). Guru bersama siswa meninjau ulang kegiatan dari hasil baca (review). Setelah melakukan kegiatan review, guru dan siswa melakukan diskusi selanjutnya membimbing siswa membuat kesimpulan tentang hasil bacaan. Setelah itu, guru memberikan kesempatan bertanya kepada siswa, dan menjelaskan kembali cara menemukan informasi dari teks yang dibaca dan cara menentukan gagasan utama tiap-tiap paragraf teks yang dibacanya. Pada kegiatan penutup, guru membimbing siswa untuk merangkum materi pembelajaran. Guru memotivasi siswa untuk rajin belajar di rumah selanjutnya memberikan tugas rumah kepada siswa.

Pada pertemuan kedua kegiatan awal yang dilakukan guru adalah menyampaikan tujuan pembelajaran yakni: (a) siswa dapat membuat pertanyaan berdasarkan teks yang dibaca, (b) siswa dapat menyimpulkan hasil bacaan. Selanjutnya guru menjelaskan kembali proses pembelajaran dengan metode SQ3R. Setelah menyampaikan tujuan pembelajaran, guru mengadakan apersepsi melalui pertanyaan berikut: (a) siapa yang ingat judul teks yang kita bahas pada pertemuan yang lalu? (b) perkelahian antar pelajar biasa disebut dengan.... (c) sebutkan 4 faktor psikologis yang menyebabkan perkelahian antar pelajar! Untuk membangkitkan respon siswa, guru melakukan tanya jawab tentang hobi membaca, dan keuntungan membaca sebagai berikut: (a) apakah banyak informasi yang kita peroleh setelah membaca sebuah buku atau teks? (b) apa yang harus dilakukan agar siswa menjadi pintar? Setelah masuk kegiatan inti, guru membagikan lembar kerja siswa (LKS) dalam bentuk teks bacaaan yang berjudul "Pendidikan Agama Sejak Dini" dan daftar 
pertanyaan kepada masing-masing siswa selanjutnya menjelaskan kepada siswa cara mengerjakan LKS. Guru mengarahkan siswa untuk melakukan survey teks bacaan. Guru membimbing siswa membuat pertanyaan tentang isi bacaan (question). Guru mengarahkan siswa membaca teks bacaan (read). Guru membimbing siswa menjawab pertanyaan (recite). Guru bersama siswa meninjau ulang kegiatan dari hasil baca (review). Setelah melakukan kegiatan review, guru dan siswa melakukan diskusi selanjutnya membimbing siswa membuat kesimpulan tentang hasil bacaan. Setelah itu, guru memberikan kesempatan bertanya kepada siswa, dan menjelaskan kembali cara membuat pertanyaan berdasarkan teks yang dibaca dan cara menyimpulkan hasil bacaan. Pada kegiatan penutup, guru membimbing siswa untuk merangkum materi pembelajaran. Guru memotivasi siswa untuk rajin belajar di rumah selanjutnya memberikan tugas rumah kepada siswa.

Skor perolehan guru pada siklus I pertemuan pertama adalah 44 dan pertemuan kedua adalah 51 sedangkan skor maksimum adalah 75. Keberhasilan aktivitas mengajar guru dihitung berdasarkan skor perolehan guru dibagi dengan skor maksimum dikalikan seratus persen sehingga persentase keberhasilan aktivitas mengajar guru siklus I pertemuan pertama adalah $68,00 \%$ dan pertemuan kedua 74,67\%. Skor perolehan siswa pada siklus I pertemuan pertama adalah 51 dan pertemuan kedua adalah 55 sedangkan skor maksimum adalah 75. Keberhasilan aktivitas belajar siswa dihitung berdasarkan skor perolehan siswa dibagi dengan skor maksimum dikalikan seratus persen, sehingga persentase keberhasilan aktivitas belajar siswa siklus I pertemuan pertama adalah $68,00 \%$ dan pertemuan kedua 73,33\%. Hasil belajar siswa pada pembelajaran siklus I, siswa yang memperoleh nilai $<70$ berjumlah 10 orang $(38,46 \%)$, siswa yang memperoleh nilai $\geq 70$ berjumlah 16 orang $(61,54 \%)$. Berdasarkan nilai siswa pada tabel 2 , ketuntasan belajar siswa mencapai $61,54 \%$, dimana siswa yang memperoleh nilai $\geq 70$ berjumlah 16 orang sedangkan siswa yang belum mencapai ketuntasan belajar berjumlah 10 orang.

Hasil refleksi pada tindakan siklus I ini penerapan metode SQ3R dalam pembelajaran membaca belum sempurna sesuai dengan yang diharapkan, masih banyak siswa yang belum mencapai ketuntasan belajar. Besarnya jumlah siswa yang belum mencapai ketuntasan belajar siswa disebabkan oleh proses pembelajaran yang kurang baik; komponen skenario pembelajaran belum dilaksanakan secara maksimal oleh guru. Siswa tidak biasa membuat pertanyaan, sehingga informasi teks yang dibaca tidak didapat. Analisis terhadap observasi dijadikan sebagai bahan untuk menentukan tindakan selanjutnya. Setelah diadakan refleksi antara observer dan peneliti maka disimpulkan dua hal berikut.

1) Sebagian siswa belum aktif dalam proses pembelajaran sehingga jumlah siswa yang belum mencapai ketuntasan belajar masih besar yakni 38,46\%.

2) Guru tidak melaksanakan pembelajaran secara sistematis sesuai skenario pembelajaran metode SQ3R.

\section{Tindakan Siklus II}

Pada pertemuan pertama kegiatan awal yang dilakukan guru adalah menyampaikan tujuan pembelajaran yakni: (a) siswa dapat menemukan informasi dari teks yang dibaca, dan (b) siswa dapat menentukan gagasan utama tiap-tiap paragraf teks yang dibacanya. Selanjutnya guru menjelaskan proses pembelajaran dengan metode SQ3R. Setelah menyampaikan tujuan pembelajaran, guru mengadakan apersepsi melalui pertanyaan berikut: (a) apa judul teks yang kita bahas pada pertemuan yang lalu? (b) apa kesimpulan dari bacaan yang dibahas pada minggu lalu? Untuk membangkitkan respon siswa, guru melakukan tanya jawab tentang hobi membaca, dan keuntungan membaca sebagai berikut: (a) siapa yang rajin membaca? (b) manakah yang lebih pintar antara siswa yang rajin membaca dan siswa yang malas membaca? Setelah masuk kegiatan inti, guru membagikan lembar kerja siswa (LKS) dalam bentuk teks bacaaan yang berjudul "Pupuk yang Aman" dan daftar pertanyaan kepada masing-masing siswa selanjutnya menjelaskan kepada siswa cara mengerjakan LKS. Guru mengarahkan siswa untuk melakukan survey teks bacaan. Guru membimbing siswa membuat pertanyaan tentang isi bacaan (question). Guru mengarahkan siswa membaca teks bacaan (read). Guru membimbing siswa menjawab pertanyaan (recite). Guru bersama siswa meninjau ulang kegiatan dari hasil 
baca1(review). Setelah melakukan kegiatan review, guru dan siswa melakukan diskusi selanjutnya membimbing siswa membuat kesimpulan tentang hasil bacaan. Setelah itu, guru memberikan kesempatan bertanya kepada siswa, dan menjelaskan kembali cara menemukan informasi dari teks yang dibaca dan cara menentukan gagasan utama tiap-tiap paragraf teks yang dibacanya. Pada kegiatan penutup, guru membimbing siswa untuk merangkum materi pembelajaran. Guru memotivasi siswa untuk rajin belajar di rumah selanjutnya memberikan tugas rumah kepada siswa.

Pada pertemuan kedua kegiatan awal yang dilakukan guru adalah menyampaikan tujuan pembelajaran yakni: (a) siswa dapat membuat pertanyaan berdasarkan teks yang dibaca, (b) siswa dapat menyimpulkan hasil bacaan. Selanjutnya guru menjelaskan kembali proses pembelajaran dengan metode SQ3R. Setelah menyampaikan tujuan pembelajaran, guru mengadakan apersepsi melalui pertanyaan berikut: (a) siapa yang ingat judul teks yang kita bahas pada pertemuan yang lalu? (b) apa tujuan pembelajaran kita pada pertemuan yang lalu? Untuk membangkitkan respon siswa, guru melakukan tanya jawab tentang hobi membaca, dan keuntungan membaca sebagai berikut: (a) mana yang lebih baik rajin membaca buku cerita atau rajin membaca buku pelajaran? (b) untuk mempersiapkan diri menghadapi ulangan apakah kita harus rajin membaca buku pelajaran atau buku cerita? Setelah masuk kegiatan inti, guru membagikan lembar kerja siswa (LKS) dalam bentuk teks bacaaan yang berjudul "Pupuk Sabut Kelapa" dan daftar pertanyaan kepada masing-masing siswa selanjutnya menjelaskan kepada siswa cara mengerjakan LKS. Guru mengarahkan siswa untuk melakukan survey teks bacaan. Guru membimbing siswa membuat pertanyaan tentang isi bacaan (question). Guru mengarahkan siswa membaca teks bacaan (read). Guru membimbing siswa menjawab pertanyaan (recite). Guru bersama siswa meninjau ulang kegiatan dari hasil baca (review). Setelah melakukan kegiatan review, guru dan siswa melakukan diskusi selanjutnya membimbing siswa membuat kesimpulan tentang hasil bacaan. Setelah itu, guru memberikan kesempatan bertanya kepada siswa, dan menjelaskan kembali cara membuat pertanyaan berdasarkan teks yang dibaca dan cara menyimpulkan hasil bacaan. Pada kegiatan penutup, guru membimbing siswa untuk merangkum materi pembelajaran. Guru memotivasi siswa untuk rajin belajar di rumah selanjutnya memberikan tugas rumah kepada siswa.

Skor perolehan guru pada siklus II adalah pertemuan pertama adalah 61 dan pertemuan kedua adalah 71 sedangkan skor maksimum adalah 75 maka persentase keberhasilan aktivitas mengajar guru pada siklus II pertemuan pertama adalah $81,33 \%$ dan pertemuan kedua adalah 94,67\%. Skor perolehan siswa pada siklus II pertemuan pertama adalah 61 dan pertemuan kedua adalah 71 sedangkan skor maksimum adalah 75 maka keberhasilan aktivitas belajar siswa pada siklus II pertemuan pertama adalah $81,33 \%$ dan pertemuan kedua adalah $94,67 \%$. Hasil belajar siswa pada pembelajaran siklus II, siswa yang memperoleh nilai rentang 0-69 berjumlah 2 orang $(7,69 \%)$ dan siswa yang memperoleh nilai rentang 70-100 berjumlah 24 orang $(92,31 \%)$. Evaluasi pada siklus II menunjukkan bahwa ketuntasan belajar siswa sebesar $92,31 \%$ dan telah mencapai indikator keberhasilan penelitian maka pelaksanaan tindakan dihentikan pada siklus II.

\section{Pembahasan \\ Aktivitas Mengajar Guru}

Aktivitas mengajar guru pada penelitian ini diketahui melalui hasil observasi pada setiap siklus tindakan. Hasil observasi siklus I menunjukkan bahwa skor perolehan guru pada siklus I pertemuan pertama adalah 51 dan pertemuan kedua adalah 56 sedangkan skor maksimum adalah 75. Keberhasilan aktivitas mengajar guru dihitung berdasarkan skor perolehan guru dibagi dengan skor maksimum dikalikan seratus persen sehingga persentase keberhasilan aktivitas mengajar guru siklus I pertemuan pertama adalah $68,00 \%$ dan pertemuan kedua $74,67 \%$

Melihat kekurangan yang masih ada serta hasil belajar siswa belum mencapai indikator keberhasilan yang telah ditetapkan, maka penelitian dilanjutkan pada tindakan siklus II. Hal-hal yang harus diperbaiki pada tindakan siklus II adalah guru lebih mengaktifkan siswa dan membimbing siswa untuk membuat pertanyaan tentang isi teks bacaan. Guru mengelola tahapan kegiatan 
pembelajaran dengan baik berdasarkan skenario pembelajaran dengan metode SQ3R. Proses pembelajaran yang baik berpengaruh peningkatan skor perolehan guru dan siswa. Skor perolehan guru pada siklus II adalah pertemuan pertama adalah 61 dan pertemuan kedua adalah 71 sedangkan skor maksimum adalah 75 maka persentase keberhasilan aktivitas mengajar guru pada siklus II pertemuan pertama adalah $81,33 \%$ dan pertemuan kedua adalah $94,67 \%$.

\section{Aktivitas Belajar Siswa}

Aktivitas belajar siswa dipengaruhi oleh aktivitas mengajar guru. Bila aktivitas mengajar guru baik maka aktivitas belajar siswa akan baik pula demikian sebaliknya. Jika aktivitas mengajar guru terdapat kekurangan maka proses belajar siswa akan bermasalah. Hasil observasi aktivitas belajar siswa siklus I menunjukkan bahwa siswa belum memahami materi pelajaran dengan baik sehingga berpengaruh pada skor perolehan siswa. Skor perolehan siswa pada pembelajaran siklus I pertemuan pertama adalah 51 dan pertemuan kedua adalah 55 sedangkan skor maksimum adalah 75 . Keberhasilan aktivitas belajar siswa dihitung berdasarkan skor perolehan siswa dibagi dengan skor maksimum dikalikan seratus persen, sehingga persentase keberhasilan aktivitas belajar siswa siklus I pertemuan pertama adalah $68,00 \%$ dan pertemuan kedua $73,33 \%$. Hasil observasi siklus II menunjukkan bahwa skor perolehan siswa pertemuan pertama adalah 61 dan pertemuan kedua adalah 71 maka keberhasilan aktivitas belajar siswa pada siklus II pertemuan pertama adalah $81,33 \%$ dan pertemuan kedua adalah $94,67 \%$. Persentase aktivitas belajar siswa siklus I dan siklus II menunjukkan peningkatan dan telah mencapai indikator keberhasilan.

\section{Hasil Belajar}

Hasil belajar yang dimaksud dalam penelitian ini adalah kemampuan membaca siswa dalam bentuk rata-rata nilai dan persentase ketuntasan belajar. Hasil belajar siswa diperoleh melalui tes kemampuan membaca siswa pada setiap akhir siklus tindakan. Hasil evaluasi siklus I menunjukkan bahwa rata-rata nilai siswa adalah 69,81 dan siswa yang mencapai ketuntasan belajar sebesar $61,54 \%$. Hasil belajar siswa pada evaluasi siklus I belum mencapai indikator keberhasilan sehingga tindakan perbaikan pembelajaran dilanjutkan ke siklus II. Setelah dilakukan perbaikan pada siklus II, diadakan evaluasi. Hasil evaluasi siklus II menunjukkan bahwa rata-rata hasil belajar adalah 81,15 dan siswa yang mencapai ketuntasan belajar mencapai $92,31 \%$.

Hasil belajar siswa siklus II telah mencapai indikator yang telah ditetapkan. Sedangkan hasil observasi terhadap pelaksanaan pembelajaran bisa dikatakan sempurna, yakni seluruh komponen dalam skenario pembelajaran telah dilaksanakan dengan baik sesuai yang diharapkan. Karena belajar siswa telah tuntas dan komponen dalam skenario pembelajaran telah dilaksanakan maka hipotesis tindakan telah tercapai yakni kemampuan membaca siswa kelas VI SD Negeri Lemo Bajo dapat ditingkatkan dengan penggunaan metode SQ3R. Membaca dalam penelitian ini adalah proses aktif dari pikiran yang dilakukan melalui mata siswa terhadap bacaan yang diberikan guru. Dalam kegiatan membaca, pembaca memproses informasi dari teks yang dibaca untuk memperoleh makna. Membaca merupakan kegiatan yang penting dalam kehidupan sehari-hari, karena membaca tidak hanya untuk memperoleh informasi, tetapi berfungsi sebagai alat untuk memperluas pengetahuan bahasa seseorang. Dengan demikian, anak sejak kelas awal Sekolah Dasar perlu memperoleh latihan membaca dengan baik khususnya membaca lancar.

Berdasarkan hasil penelitian ini, maka guru memperoleh beberapa manfaat dari penggunaan metode ini dalam kegiatan membaca, pertama, adanya tahap survey terhadap bacaan yang dihadapi memberi kemungkinan pada pembaca untuk menentukan apakah materi yang dihadapinya itu sesuai dengan keperluannya atau tidak. Hal itu berarti jika bacaan itu memang diperlukannya, tentu pembaca akan meneruskan kegiatan membacanya. Jika tidak, pembaca akan mencari bahan lain yang sesuai dengan kebutuhannya. Kedua, metode SQ3R memberi kesempatan kepada para pembaca untuk berlaku fleksibel. Artinya pengaturan kecepatan membaca untuk setiap bagian bahan bacaan tidaklah harus sama. Pembaca akan memperlambat tempo bacaannya manakala bertemu dengan hal-hal yang relatif baru baginya, yang memerlukan perenungan untuk dapat memahaminya, dan 
bagian-bagian bacaan yang berisi informasi yang diperlukan. Sebaliknya, pembaca akan menaikkan tempo kecepatan bacanya, jika bagian-bagian bacaan itu dipandang kurang relevan dengan kebutuhannya atau sudah dikenalinya. Ketiga, metode SQ3R membekali pembaca dengan metode belajar yang sistematis. Belajar dengan menggunakan metode tertentu akan menghasilkan efisiensi dan efektifitas hasil belajar yang lebih baik daripada tidak bermetode. Penerapan metode ini dalam pembelajaran akan menghasilkan pemahaman yang komprehensif, bukan ingatan. Pemahaman yang komprehensif relatif akan bertahan lebih lama tersimpan di dalam otak kita, daripada hanya sekadar mengingat fakta.

Berdasarkan hasil yang diperoleh dari penelitian ini dapat disimpulkan bahwa dalam pembelajaran membaca dengan metode SQ3R adalah proses pembelajaran dengan lima tahap, yakni: survey, membuat pertanyaan (question), membaca terbimbing (read), mencatat jawaban pertanyaan (recite), meninjau ulang kegiatan dari hasil baca (review). Tahap survei bacaan dilakukan untuk mendapatkan gagasan umum apa yang akan dibaca. Lalu dengan mengajukan berbagai pertanyaan pada diri sendiri yang jawabannya diharapkan terdapat dalam bacaan tersebut akan lebih memudahkan pembaca memahami bacaan. Kemudian dengan mencoba mengutarakan dengan katakata sendiri pokok-pokok pentingnya, pembaca akan menguasai dan mengingatnya lebih lama. Sehingga metode ini memungkinkan para siswa untuk belajar secara sistematis dengan bantuan langkah-langkah kerja yang tepat dan efisien.

\section{Simpulan}

Berdasarkan hasil penelitian dan pembahasan, disimpulkan bahwa aktivitas mengajar guru, aktivitas belajar siswa, dan kemampuan membaca siswa kelas VI SD Negeri Lemo Bajo dapat ditingkatkan melalui penerapan metode SQ3R. Peningkatan aktivitas mengajar guru ditunjukkan oleh peningkatan persentase keberhasilan aktivitas mengajar guru. Persentase keberhasilan aktivitas mengajar guru siklus I pertemuan pertama adalah $68,00 \%$ dan pertemuan kedua $74,67 \%$, meningkat menjadi $81,33 \%$ pada siklus II pertemuan pertama dan $94,67 \%$ pertemuan kedua. Peningkatan aktivitas belajar siswa ditunjukkan oleh peningkatan persentase keberhasilan aktivitas belajar siswa. Persentase keberhasilan aktivitas belajar siswa siklus I pertemuan pertama adalah $68,00 \%$ dan pertemuan kedua $73,33 \%$, meningkat menjadi $81,33 \%$ pada siklus II pertemuan pertama dan $94,67 \%$ pertemuan kedua. Peningkatkan kemampuan menulis siswa ditunjukkan oleh peningkatan rata-rata nilai dan ketuntasan belajar siswa. Rata-rata nilai siswa siklus I adalah 73,23 meningkat menjadi 79,50 pada siklus II. Ketuntasan belajar siswa pada siklus I adalah $61,54 \%$ meningkat menjadi $92,31 \%$ pada siklus II.

\section{Daftar Pustaka}

Dimyati \& Mudjono, 2003. Belajar dan Pembelajaran. Jakarta: Bumi Aksara.

Lukman. 2009. Peningkatan Kemampuan Membaca dengan Strategi SQ3R pada Siswa Kelas VI SDN 2 Nganganaumala Kota Bau-Bau Tahun Ajaran 2009/2010. Skripsi. Kendari: FKIP. UHO.

La Mica. 2010. Meningkatkan Kemampuan Membaca Siswa Kelas VI SDN 2 Wamboule Kabupaten Buton Utara melalui Metode SQ3R. Skripsi. Kendari: FKIP. UHO.

Soedarso. 2004. Sistem Membaca Efektif. Jakarta: Gramedia Pustaka Utama 